\title{
Deskripsi Keaktifan Belajar Siswa Terhadap Mata Pelajaran IPA di SMP Negeri 18 Kota Jambi
}

\author{
Nur Ika Sandi Pratiwi ${ }^{1}$ \\ ${ }^{1}$ Pendidikan Fisika, Universitas Jambi, Jambi, Indonesia
}

\begin{tabular}{l} 
Article Info \\
\hline Article history: \\
Received Jun 30, 2020 \\
Revised Agu 7, 2020 \\
Accepted Sep 9, 2020 \\
\hline
\end{tabular}

\section{Keywords:}

IPA

Keaktifan Belajar

Siswa SMP

\begin{abstract}
ABSTRAK
Tujuan Penelitian: Tujuan penelitian ini adalah untuk mengetahui keaktifan belajar siswa terhadap mata pelajaran IPA di SMP Negeri 18 Kota Jambi.

Metodologi: Metode penelitian yang digunakan metode penelitian campuran dengan desain explanatory. Subjek penelitian adalah siswa SMP Negeri 18 Kota Jambi berjumlah 147 siswa. Teknik analsis data menggunakan statistik deskriptif untuk data kuantitatif dan analisis Miles Huberman untuk data kualitatif.
\end{abstract}

Temuan utama: Hasil penelitian pada kedua indicator menunjukkan bahwa siswa dikategorikan memiliki keaktifan belajar baik pada indikator "Rasa Ingin Tahu Yang Tinggi (44,9\%)". Kemudian, siswa dikategorikan memiliki keaktifan belajar cukup pada indikator "Pantang Menyerah $(45,6 \%)$ ". Presentase tinggi dari kedua indikator didukung oleh hasil wawancara yang menyatakan bahwa siswa mempunyai rasa ingin tahu yang tinggi terlihat dari siswa yang aktif bertanya dan juga tidak hanya mengandalkan materi yang diberikan oleh guru, dan siswa mepunyai semangat yang tinggi untuk belajar IPA akan tetapi mereka tidak percaya diri dengan kemampuan yang mereka miliki.

Keterbaruan penelitian: Penelitian ini merupakan penelitian yang memiliki keterbaruan pada subjek dan instrument yang digunakan, dengan mengetauhi keaktifan siswa dalam belajar, maka akan mempermudah guru utuk milih metode apa yang akan digunakan selama proses pelajaran berlangsung.

This is an open access article under the $\underline{C C B Y-N C}$ license

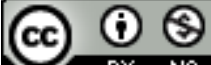

\section{Corresponding Author:}

Nur Ika Sandi Pratiwi,

Fakultas Keguruan dan Ilmu Pendidikan, Universitas Jambi

Jalan. Raya Jambi-Ma.Bulian KM 15 Mendalo Darat, Jambi, Indonesia

E-Mail: nurikapratiwi026@gmail.com

\section{PENDAHULUAN}

Pendidikan merupakan upaya pengolahan yang dilakukan oleh seseorang untuk mendapatkan pengetahuan, keterampilan, dan kebiasaan dalam hidup [1]. Pendidikan merupakan kegiatan ang sangat penting, dengan adanya pendidikan manusia dapat mengubah perilaku dan pengetahuan menjadi lebih baik [2]. Pendidikan adalah proses untuk memperoleh dan menanamkan keterampilan yang dilakukan oleh siswa [3]. Pendidikan juga bisa diartikan sebagai kegiatan yang disengaja atas input siswa untuk menimbulkan suatu hasil yang diinginkan sebagai tujuan yang ditetapkan [4]. Saat ini dunia pendidikan di Indonesia semakin berkembang, untuk meningkatkan kualitas dan kuantitas pendidikan berbagai macam pembaharuan harus dilakukan, dimana untuk meningkatkan kualitas dan kuantitas pendidikan diperlukan berbagai 
terobosan, baik dalam pengembangan kurikulum, inovasi pembelajaran dan pemenuhan sara serta prasarana pendidikan. Untuk meningkatkan kualitas pnedidikan di Indonesia, juga harus didukung oleh kualitas tenaga kependidikannya. Kompetensi guru merupakan faktor penting dalam proses belajar mengajar untuk menentukan mengajar [5]. Belajar bukan hanya diartikan sebagai proses pentransferan ilmu dari guru kepada peserta didik yang bersifat kaku, tetapi belajar lebih kearah bagaimana mengoptimalkan seluruh panca indra agar peka terhadap informasi-informasi yang didapatkan dikelas [6]. Proses pembelajaran lebih diartikan kepada kegiatan yang dirancang untuk membantu seseorang mempelajari suatu kemampuan dan atau nilai yang baru [7]. Lingkungan belajar adalah bagian dari proses belajar, didalam lingkungan belajar tidak lepas dari keberadaan siswa dan belajar [8].

Salah satu upaya dalam bidang pendidikan adalah dapat meningkatkan dan mencetak Sumber Daya Manusia (SDM) yang berkualitas [9]. Hal ini sejalan dengna yang diungkapkan [10] yang menyatakan kualitas sumber daya manusia sangat ditentukan oleh mutu pendidikan. Untuk meningkatkan kualitas SDM setiap lembaga pendidikan diharapkan lebih berfokus pada pengembangan potensi peserta didik yang berkaitan dengan karakter serta berorientasi apda aspek sikap dan tingkah laku afektif [11]. Pendidikan yang berbasis karakter merupakan pendidkan yang menerapkan metodologi dan prinsip-prinsip kearah pembentukan karakter peserta didik melalui kurikulum terintegrasi yang dikembangkan di sekolah [12]. Pendidikan karakter pada masa remaja di sekolah menengah bertujuan untuk pengembangan, oleh karena itu tugas pendidik adalah untuk mengembangkan karakter siswa.

Dalam pendidikan terdapat beberapa jenjang pendidikan yaitu Sekolah Dasar, Sekolah Mnenegah Pertama (SMP), Sekolah Menengah Atas (SMA), dan jenjang pendidikan perguruan tinggi. IPA merupakan salah satu mata pelajaran yang adalah dalam jenjang pendidikan Sekolah menengah Pertama (SMP). IPA maerupakan Ilmu yang mempelajari tentang fenomena alam dan segala sesuatu yang ada dialam [13]. IPA adalah suatu kumpulan teori yang sistematis, dan dalam penggunaannya secara umum terbatas pada gejalagejala alam, lahir dan berkembang melalui metode ilmiah seperti observasu dan eksperimen serta menunutut sikap ilmiah seperti rasa ingin tahu, terbuka, jujur, dan sebagainya [14]. Sains dan teknologi telah menjadi factor penting bagi pembangunan berkelanjutan diseluruh dunia, keduanya telah memberikan kontribusi yang sangat besar bagi kemajuan material Negara-negara [15]. Mata pelajaran IPA SMP merupakan gabungan dari tiga mata pelajaran yaitu biologi, fisika, dan kimia dimana sebagian besar materinya berupa pemahaman konsep dan hafalan seta rumus-rumus dengan istilah-istilah asing, sehingga hal ini bukanlah hal yang mudah bagi guru untuk membuat siswa mampu menghafal dan memahaminya [16]. Melalui pembelajaran IPA siswa diharapkan dapat mengembangkan kemampuan penalaran (reasoning) dalam pemikiran analisis induktif dan deduktif menggunakan konsep dan prinsip sains untuk menjelaskan peristiwa alam dan pemecahan masalah baik secara kualitatif maupun kuantitatif [17]. Hal ini sesuai yang diungkapkan oleh [18] yang menyatakan bahwa Pembelajaran IPA yang sebaiknya dilakukan adalah pembelajaran yang dapat menyiapkan peserta didik untuk melek IPA dan teknologi, mampu berpikir logis, kritis dan kreatif. Sains juga merupakan cabang ilmu pengetahuan yang memiliki keunikan dan karakteristik, keunikan sains terletak pada keberadaan konsep yang abstrak dan membutuhkan idealisasi melalui pemodelan matematika, hal ini membuat sains dikatakan sebagai subjek yang sulit baik untuk dipelajari aupun diajarkan [19]. IPA erat kaitannya dengan alam sehingga menjadikan mata pelajaran IPA menjadi mata pelajaran yag terbilang sulit bagi siswa karena bersifat abstrak [20]. Ketika siswa mempunyai rasa ingin tahu yang tinggi terhadap sains maka ini akan membuat siswa meluangkan waktu untuk menambah waktu belajar IPA. Belajar mengajar merupakan proses yang beragam [21]. Belajar adalah suatu proses perubahan di dalam kepribadian manusia, dan perubahan tersebut ditampakkan dalam bentuk peningkatan kualitas dan kuantitas tingkah laku seperti peningkatan kecakapan, pengetahuan, sikap, kebiasaan, pemahaman, keterampilan, daya pikir, dan lain-lain pemahaman [22]. Selanjutnya [23], menyatakan belajar merupakan proses ketika seseorang memperoleh berbagai kecakapan, keterampilan, dan sikap. Terdapat banyak faktor yang mempengaruhi capaian pembelajaran, faktor-faktor tersebut diantaranya adalah factor internal, factor eksternal, dan factor pendekatan belajar [24]. Sistem pendidikan yang lebih mementingkan aspek kognitif, dengan proses pembelaaan yang pasif dan kaku, membuat proses belajar menjadi sangat tidak menyenangkan dan penuh beban, yang tanpa disadari sistem yang demikian telah membunuh karakter siswa sehingga siwa menjadi tidak kreatif, tidak percaya diri, tertekan, bahkan stress, serta tidak cinta belajar [25]. Keaktifan siswa dalam belajar merupakan persoalan penting yang mendasar dan harus dipahami, disadari dan harus dikembangkan oleh setiap guru dalam proses pembelajaran. Dengan demikian berarti harus dapat diterapkan oleh siswa dalam setiap bentuk kegiatan belajar. Keaktifan belajar ditandai oleh adanya keterlibatan secara optimal, baik intelektual, emosi dan fisik [26]. Hal ini sejalan dengan yang diungkapkan oleh [27], yang menyatakan bahwa keaktifan belajar merupakan suatu kegiatan yang dilakukan oleh siswa selama proses pembelajaran berlangsung, dimana siswa bekerja atau berperan aktif dalam pembelajaran di kelas, sehingga dengan demikian siswa akan memperoleh pengetahuan, pengalaman, dan pemahaman serta aspek-aspek lain mengenai apa yang sudah dilakukan. Kekatifan belajar siswa juga diartikan sebagai suatu proses kegiatan belajar mengajar yang menuntut siswa 
terlibat aktif dan berpartisipasi dalam proses pembelajaran sehingga mampu mengubah tingkah laku siswa [28]. Keaktifan peserta didik didalam proses pembelajaran menyebabkan interaksi yang tinggi antara pendidik dan juga peserta didik, hal ini dapat menyebabkan suasana kelas menjadi segar dan kondusif dimana masing-masing peserta didik dapat melibatkan kemampuannya secara maksimal [29]. Keaktifan di kelas terjadi apabila terdapat kegiatan yang dilakukan oleh guru dan siswa, dimana yang dimaksud dengan keaktifan belajar dalam hal ini adalah keaktifan yang sifatnya berupa fisik ataupun mental dalam kegiatan pembelajaran guna menunjang keberhasilan proses belajar mengajar [30]. Kegiatan fisik dan psikis yang dimunculkan atau dilakuakn oleh siswa mampu mempengaruhi hasil belajar siswa karena siswa yang aktif mampu meningkatkan hasil belajar [31].

Landasan pembelajaran aktif adalah keterlibatan siswa secara aktif dalam penguasaan pengetahuan, keterampilan, dan sikap mereka [32]. Active larning includes activities in which students are engaged. This means the students are doing something and thinking about what they are doing [33]. Pembelajaran aktif mencakup kegiatan dimana siswa terlibat ini berate siswa sedang melakukan sesuatu dan berpikir tentang apa yang mereka lakukan. Pembelajaran aktif biasanya digambarkan sebagai pembelajaran yang berpusat pada siswa dimana peserta didik berpartisipasi dalam membangun pengetahuan kolaboratif [34]. Keaktifan belajar berarti suatu usaha atau kerja yang dilakukan dengan giat dalam belajar [35]. Siswa merupakan manusia belajar yang aktif dan selalu ingin tahu [36]. Dalam kegiatan pembelajaran peserta didik tidak hanya dituntut untuk aktif, tetapi juga dituntut kreativitasnya, karena kreativitas dapat menciptakan situasi yang baru tidak monoton dan menarik sehingga siswa akan lebih terlibat dalam pembelajaran [29].

Karena belum adanya penelitian yang mengukur tentang keaktifan belajar siswa pada mata pelajaran IPA di Kota Jambi, khususnya di SMP Negeri 18 Kota Jambi, maka peneliti tertarik untuk melakukan penelitian ini. Diharapkan hasilnya dapat dijadikan acuan untuk penelitian selanjutnya atau dapat menjadi pedoman bagi guru untuk mengukur keaktifan belajar yang dimiliki siswa. Adapun tujuan dilakukannya penelitian ini adalah untuk mengetahui bagaimana keaktifan belajar siswa terhadap mata pelajaran IPA di Sekolah Menengah Pertama (SMP) Negeri 18 Kota Jambi.

\section{METODE PENELITIAN}

Penelitian ini merupakan penelitian mix method dengan menggunakan desain explanatory. Menurut [37], desain explanatory merupakan desain penelitian dalam penelitian campuran yang ditandai dengan pengumpulan dan analisis data kuantitatif dalam fase pertama kemudian diikuti oleh pengumpulan dan analisis data kualitatif pada fase kedua yang dibangun berdasarkan hasil dari kuantitatif awal.

Penelitian ini dilaksanakan di Sekolah Menengah Pertama Negeri 18 Kota jambi. Populasi dalam penelitian ini adalah seluruh siswa kelas VII, VIII, dan IX SMP Negeri 18 Kota Jambi. Sedangkan sampel yaitu bagian kecil yang diambil untuk mewakili populasinya yaitu berjumlah 147 orang.

Teknik pengumpulan data dalam penelitian ini menggunakan instrumen berupa angket atau kuesioner dan lembar wawancara. Pada penelitian ini menggunakan angket keaktifan belajar yang peneliti adaptasi dari penelitian [38]. Selanjutnya angket ini peneliti uji kelayakannya (validitas dan reliabilitas). Angket keaktifan belajar ini terdiri dari 25 pernyataan yang menggunakan skala likert 5 yaitu Selalu (SL), Sering (SR), Kadang-Kadang (KK), Jarang (JR), dan Tidak Pernah (TP). Skor untuk jawaban dari pertanyaan positif adalah $\mathrm{SL}=5, \mathrm{SR}=4, \mathrm{KK}=3, \mathrm{JR}=2$, dan $\mathrm{TP}=1$. Selain itu, dalam penelitian ini juga menggunakan lembar wawancara. Saat dilakukan wawancara selain harus menggunakan instrument sebagai pedoman, juga dapat menggunakan alat bantu lain seperti tape recorder, gambar, brosur, dan material lain yang dapat membantu pelaksanaan wawancara menjadi lancar.

Prosedur penelitian ini dilakukan mulai dari menyebarkan angket atau kuesioner, kemudian dilakukan analisis data kuantitatif, selanjutnya identifikasi hasil untuk melakukan tindak lanjut. Setelah itu dilakuakan pengumpulan data kualitatif, selanjutnya menganalisis data kualitatif, kemudian didapatkan hasil data kualitatif dan terakhir interpretasikan hasil penelitian kuantitatif dan kualitatif.

Analisis data pada penelitian ini menggunakan data analisis kuantitatif menggunakan program SPSS 24 untuk mencari statistik deskriptif. Statistik deskriptif merupakan suatu gambaran atau penyajian data dalam jumlah yang besar, dalam hal ini berupa frekuensi ringkasan, misalnya, modus, mean, median, maksimum, minimum dan standar deviasi [39]. Kemudian dilanjutkan dengan wawancara yang diperuntukkan untuk memperkuat hasil data. Analisis data kualitatif ini dengan menggunakan analisis Miles Huberman.

\section{HASIL DAN PEMBAHASAN}

Adapun hasil dari penelitian ini disajikan dalam tabel dibawah ini:

\subsection{Rasa Ingin Tahu Yang Tinggi}

Deskripsi Keaktifan Belajar Siswa Terhadap Mata Pelajaran IPA di SMP ... (Nur Ika Sandi Pratiwi) 
Berikut adalah hasil analisis data deskriptif menggunakan SPSS dari data angket keaktifan belajar siswa untuk indikator rasa ingin tahu yang tinggi, dengan hasil seperti pada tabel 1.

Table 1. Hasil indikator Rasa Ingin Tahu Yang Tinggi

\begin{tabular}{|c|c|c|c|c|c|c|c|}
\hline \multicolumn{3}{|c|}{ Klasifikasi } & \multirow{2}{*}{$\%$} & \multirow{2}{*}{ Mean } & \multirow{2}{*}{ Median } & \multirow{2}{*}{ Min } & \multirow{2}{*}{$\operatorname{Max}$} \\
\hline Rentang & Sikap & Frek & & & & & \\
\hline $5,0-9,0$ & Sangat tidak baik & 1 & 0,7 & & & & \\
\hline $9,1-13,0$ & Tidak baik & 35 & 23,8 & & & & \\
\hline $13,1-17 ., 0$ & Cukup & 45 & 30,6 & 16.1 & 16.0 & 7.0 & 25 \\
\hline $17,1-21,0$ & Baik & 61 & 41,5 & & & & \\
\hline $21,1-25,0$ & Sangat Baik & 5 & 3,4 & & & & \\
\hline
\end{tabular}

Berdasarkan tabel 1, tercatat bahwa sebanyak 44,9\% (66 dari 147) siswa berkategori baik dengan skor maksimal dari keseluruhan pernyataan di indikator rasa ingin tahu yang tinggi adalah 25. Hal ini menunjukkan bahwa siswa paling banyak mengakui tentang adanya rasa ingin tahu yang tinggi selama terjadinya proses pembelajaran IPA, dan siswa menyadari bahwa mempelajari IPA disekolah merupakan hal yang sangat penting meskipun terkadang siswa merasa sangat sulit untuk memahami konsep-konsep yang ada di IPA. Kemudian ada sebanyak 30,6\% (45 dari 147) siswa berkategori cukup yang berarti siswa masih bingung mengenai adanya peran IPA dalam kehidupan sehari-hari, hal ini ditunjukkan dari hasil angket yang menyatakan bahwa mereka masih ragu untuk mempunyai rasa ingin tahu yang tinggi terhadap IPA. Sedangkan sebanyak 24,5\% (36 dari 147) siswa berkategori tidak baik hal ini menunjukkan siswa menganggap mempelajari IPA bukanlah hal yang terlau penting, dan siswa tidak mengetahui apa manfaat yang akan didapatkan ketika siswa mempelajari IPA, selain hanya mendapatkan nilai yang bagus. Hal ini ditunjukkan dari mereka tidak mempunyai rasa ingin tahu yang tinggi terhadap IPA.

Berdasarkan hasil analisis angket pada tabel 1 dengan indikator rasa ingin tahu yang tinggi dari IPA di SMP Negeri 18 Kota Jambi, memperlihatkan bahwa peserta didik dominan berkategori baik. Rasa ingin tahu merupakan sikap atau tinadakan yang selalu berupaya untuk mengetahui lebih lanjut, mendalam dan meluas dari sesuatu yang dipelajarinya, dilihat serta didengar [40]. Dari hasil wawancara yang telah dilakukan memperlihatkan bahwa meskipun IPA/sains itu sulit bagi peserta didik, karena dalam pelajaran IPA ini peserta didik dituntut untuk mempelajari konsep-konsep yang bersifat abstrak, hafalan dan juga rumus-rumus, tetapi mereka tetap mempunyai rasa ingin tahu yang tinggi terhadap mata pelajaran IPA, hal ini dapat dilihat dari pengakuan siswa yang mengatakan bahwa selain mereka mendapatkan materi dari guru, jika materi yang diberikan oleh guru dirasa kurang lengkap siswa berusaha untuk mencari materi dari sumber atau literatur yang lain. Selain itu, ketika guru menjelaskan suatu materi IPA, apabila ada hal yang belum mereka ketahui mereka akan akan aktif bertanya untuk menggali pengetahuan mereka secara mendalam. Sehingga mereka mengetahui bahwa konsep dan rumus, serta hafalan tersebut apabila diterapkan dalam kehidupan sehari-hari akan banyak membawa manfaat. Selain itu, karena mempunyai rasa ingin tahu yang tinggi siswa menjadi mengetahui bagaimana peran IPA dapat menyelesaikan permasalahan yang ada dalam kehidupan sehari-hari, dan siswa mengetahui bagaimana peran IPA dalam membuat kehidupan lebih baik. Hal ini sejalan dengan yang diungkapakan oleh [41], yang menyatakan bahwa rasa ingin tahu yang tinggi yang dimiliki oleh seorang siswa dapat mendorong siswa untuk menemukan hubungan antar konsep sehingga dapat ditemukan konsep baru. Sehingga berdasarkan hasil analisis data wawancara yang dilakukan, diperoleh hasil bahwa siswa SMPN 18 Kota Jambi memiliki keaktifan belajar IPA yang positif mengenai adanya peran IPA dalam kehidupan sehari-hari. Hal ini terlihat dari antusias siswa untuk mengikuti pembelajaran IPA dikelas, dan juga rasa ingin tahu yang tinggi yang dimiliki oleh siswa. Apabila siswa mempunyai kesadaran dan rasa ingin tahu yang tinggi akan manfaat dari IPA, maka siswa akan merasa bahwa IPA adalah ilmu yang penting untuk dipelajari. IPA akan berubah menjadi mata pelajaran yang menyenangkan bagi siswa, dan siswa akan mengaitkan kejadian disekitar mereka dengan ilmu sains.

\subsection{Pantang Menyerah}

Berikut adalah hasil analisis data deskriptif menggunakan SPSS dari data angket keaktifan belajar siswa untuk indikator pantang menyerah, dengan hasil seperti pada tabel 2.

Tabel 2. Hasil dari indikator Pantang Menyerah

\begin{tabular}{|c|c|c|c|c|c|c|c|}
\hline \multicolumn{3}{|c|}{ Klasifikasi } & \multirow{2}{*}{$\%$} & \multirow{2}{*}{ Mean } & \multirow{2}{*}{ Median } & \multirow{2}{*}{ Min } & \multirow{2}{*}{ Max } \\
\hline Rentang & Sikap & Frek & & & & & \\
\hline $4,0-7,2$ & Sangat tidak baik & 5 & 3,4 & & & & \\
\hline $7,3-10,4$ & Tidak baik & 17 & 11,6 & 12.9 & 13.0 & 7.0 & 19 \\
\hline $10,5-13,6$ & Cukup & 67 & 45,6 & & & & \\
\hline
\end{tabular}




$\begin{array}{cccc}13,7-16,8 & \text { Baik } & 48 & 32,7 \\ 16,9-20,0 & \text { Sangat Baik } & 10 & 6,8\end{array}$

Berdasarkan tabel 2, dapat dideskripsikan bahwa siswa SMPN 18 Kota Jambi dominan menjawab cukup dengan perolehan data yaitu sebesar 45,3\% (67 dari 147) berada pada kategori cukup untuk indikator pantang menyerah. Hal ini menunjukkan bahwa siswa belum mengerti tentang pentingnya IPA dalam kehidupan sehari-hari, dan memperlihatkan bahwa siswa belum bisa melihat diri sendiri sebagai ilmuwan. Dalam pembelajaran IPA indikator pantang menyerah dapat dilakukan dengan cara ketika belajar didalam kelas siswa tekun dan rajin mencatat. Selain itu dapat juga diterapkan pada saat melakukan eksperimen maupun pada saat menyelesaikan soal yang diberikan guru, dengan tidak mudah menyerah untuk mnyelesaikan soal yang diberikan, apabila soal yang diberikan dirasa sulit maka peserta didika akan berusaha menyelesaikan soal-soal tersebut dnegan cara mencari jawaban dari literature lain tidak hanya berpatokan pada apa yang diberikan oleh guru. Kemudian 39\% (58 dari 147) siswa berdasarkan analisis data termasuk dalam kategori baik. Hal ini berarti ada sebagain siswa yang sudah paham tentang pentingnya IPA, sehingga mereka memunyai sikap yang pantang menyerah terhadap pembelajaran IPA. Sedangkan sebanyak $14,9 \%$ (22 dari 148) siswa berkategori tidak baik, hal ini menunjukkan bahwa siswa tidak mengerti tentang pentingnya IPA, dan tidak bisa memperlihatkan sikap mereka sebagai seorang siswa yang berfikir kritis dan pantang menyerah dalam memecahkan masalah secara ilmiah. Sehingga berdasarkan hasil analisis data yang dilakukan, diperoleh hasil bahwa siswa SMPN 18 Kota Jambi memiliki keaktifan belajar cukup terhadap indikator pantang menyerah.

Berdasarkan hasil analisis angket pada tabel 2 dengan indikator pantang menyerah memperlihatkan bahwa siswa di SMP Negeri 18 Kota Jambi yang paling dominan adalah kategori cukup sebesar 45,3\%. Siswa yang menyetujui pernyataan ini mempunyai semangat yang tinggi dan gigih dalam setiap pembelajaran IPA baik dalam hal memahami setiap materi yang diberikan oleh guru maupun dalam hal menyelesaikan persoalan yang rumit akan tetapi mereka juga tidak percaya diri dengan kemampuan yang mereka miliki. Apabila kita melihat keseluruhan data yang diperoleh, kriteria tidak baik yaitu sebanyak 14,9\% dan kriteria baik sebanyak 39,9\%. Hasil wawancara yang telah dilakukan, bagi siswa yang mendapatkan kriteria tidak baik mengungkapkan bahwa, mata pelajaran IPA merupakan mata pelajaran yang sulit. Karena di IPA peserta didik dituntut harus menghafal teori, rumus dan juga banyak konsep-konsep yang harus dipahami. Selain itu, di IPA terkadang mereka dituntut untuk harus berhayal karena materi pembelajaran yang bersifat abstrak dan tidak pernah dilihat dalam kehidupan sehari-harinya. Sehingga ketika guru memberikan persoalan yang rumit, mereka merasa malas untuk mengerjakan soal tersebut karena merasa tidak paham dengan materi pembelajaran, dan lebih memilih untuk menyalin jawaban dari teman daripada harus menyelesaikannya sendiri. Sedangkan, siswa yang memperoleh kriteria baik mengungkapkan bahwa mata pelajaran IPA merupakan mata pelajaran yang menarik untuk dipahami, karena banyak sekali manfaat yang dapat dirasakan dalam kehidupan sehari-hari dan berhubungan langsung dengan alam. Selain itu, ketika guru memberikan tugas berupa soal IPA yang rumit, siswa merasa menjadi lebih tertantang untuk menyelesaikan persoalan tersebut, ketika mereka belum dapat menyelesaikan persoalannya mereka akan terus berusaha dengan gigih untuk menyelesaikan soal tersebut sampai memperoleh jawabannya dengan benar. Hal ini menunjukkan bahwa siswa mempunyai karakter pantang menyerah. Sesuai yang diungkapkan oleh Yudha [42], bahwa pantang menyerah merupakan karakter tidak mudah putus asa dalam melakukan sesuatu, selalu bersiikap optimis, dan mudah bangkit dari keterpurukan.

Dalam proses belajar siswa yang aktif dan antusias mengikuti proses pembelajaran akan membuat pendidikan semakin berkualitas [43]. Siswa yang aktif adalah siswa yang menyusun pengetahuan mereka secara aktif, siswa merenungkan dan mengendalikan proses belajar mereka [44]. Siswa yang aktif dalam belajar adalah siswa yang terlibat dalam kegiatan pembelajaran dan berpartisipasi secara langsung pada proses pembelajaran [45]. Dalam proses pembelajaran harus ada keaktifan siswa pada awal proses pembelajaran sampai dengan selesai dan hasil belajar siswa setelah menerima pelajaran [46]. Siswa yang aktif dalam pembelajaran akan lebih semangat dan percaya diri untuk mengungkapkan pendapatnya. Siswa yang aktif dalam belajar mempunyai percaya diri yang tinggi dalam pembelajaran [47]. Keaktifan belajar dilihat saat siswa antusias menjawab pertanyaan-pertanyaan dari guru, mengerjakan tugas yang diberikan guru dan saat guru bertanya siswa menanggapi pertanyaan guru tersebut [48]. Keaktifan belajar siswa dapat terlihat dari keterlibatan siswa dalam proses belajar yang beragam seperti ketika mendengarkan penjelasan guru, diskusi, melaporkan implementasi tugas dan sebagainya [49].

Rendahnya minat siswa untuk belajar sains membuat siswa menjadi tidak aktif dalam pembelajaran [50]. Hasil belajar siswa yang rendah disebabkan karena kurangnya motivasi dan partisipasi siswa dalam belajar [51]. Siswa merasa sulit untuk memahami materi karena mereka tidak belajar secara bermakna, sehingga hasil belajar dan keaktifan siswa daam belajar kurang maksimal [52]. Siswa yang pasif dalam belajar maka aktivitas pembelajaran tidak akan berjalan optimal yang menyebabkan proses belajar tidak akan 
dilanjutkan [53]. Siswa yang tidak aktif dalam kegiatan pembelajaran menyebabkan rendahnya hasil belajar pada siswa sehingga tidak dapat mengembangkan keterampilan berpikir tingkat tinggi.

\section{KESIMPULAN}

Berdasarkan penelitian yang dilakukan, maka dapat disimpulkan bahwa dari kelima indikator keaktifan belajar siswa terhadap mata pelajaran IPA kelas VII, VIII, dan IX di SMPN 18 Kota Jambi indikator yang memiliki kriteria baik yaitu indikator Rasa Ingin Tahu yang Tinggi (44,9\%), untuk indikator pantang menyerah memperoleh kriteria cukup (45,6 \%). Siswa yang memperoleh hasil angket dengan kriteria baik dari indikator memiliki rasa ingin tahu yang tinggi menyatakan meskipun IPA merupakan mata pelajaran yang sulit, tetapi siswa tetap mempunyai rasa ingin tahu yang tinggi, ini terlihat dari selain mendapatkan materi dari guru siswa juga membaca dari referensi yang lain dan aktif bertanya ketika guru menjelaskan. Kemudian, untuk siswa yang memperoleh hasil dengan kriteria cukup untuk indikator pantang menyerah menyatakan bahwa ada semangat yang tinggi untuk belajar IPA akan tetapi mereka tidak percaya diri dengan kemampuan yang mereka miliki.

\section{UCAPAN TERIMA KASIH}

Peneliti menguvcapkan termikasih kepada seluruh pihak yang membantu sehingga penelitian ini dapat selesai dengan baik.

\section{REFERENSI}

[1] Asrial., Syahrial., D. A. Kurniawan, F. Chan, R. Septianingsih, and R. Perdana, "Multimedia innovation 4.0 in education: E-Modul Ethnoconstructivism,” Universal Journal of Educational Research, vol. 7, no. 10, pp. 20982107, 2019.

[2] Asrial, Syahrial, D.A. Kurniawan, R. Perdana, P. Nugroho, "Supporting Technology 4.0: Ethoconstructivist Multimedia for Elementary Schools," iJOE, vol. 15, no. 14, pp. 54-66, 2019.

[3] S. Syahrial, A. Asrial, D. A. Kurniawan, F. Chan, A. Hariandi, R. A. Pratama, P. Nugroho, R. Septiasari, "The Impact of Etnocontructivism in Social Affairs on Pedagogic Competencies," Journal of Evaluation and Research in Education (IJERE), vol. 8, no. 3, pp. 409-416, 2019.

[4] M. D. W. Ernawati, Haryanto, and S. CP. Nababan, "Analisis Penerapan Model Pembelajaran Kooperatif Numbered Head Together (NHT) dan Pengaruhnya Terhadap Hasil Belajar Siswa Pada Materi Struktur Atom di Kelas X SMKN 3 Kota Jambi,” J. Ind. Soc. Integ. Chem, vol. 9, no.1, pp.45-53, 2017.

[5] A. Asrial, S. Syahrial, D. A. Kurniawan, M. Subandiyo, and N. Amalina, "Exploring Obstacles In Language Learning Among Prospective Primary School Teacher," International Journal of Evaluation And Research In Education (IJERE), vol. 8, no.2, pp. 249-254, 2019.

[6] R.S. Budiarti, A. Sadikin, "Pengaruh Kwartet Animalia Dengan Model TGT Terhadap Pemahaman Materi Taksonomi Hewan Siswa SMAN 8 Kota Jambi,” Jurnal Biodik,vol. 1, no. 1, pp. 1-9, 2015.

[7] Abdurrahman, Gardjito, R. S. Budiarti, "Pengembangan Lembar Kegiaan Siswa Berbasis Penemuan Terbimbing Pada Materi Struktur Dan Fungsi Jaringan,” Jurnal Biodik, vol.1, no. 1, pp. 1-8, 2015.

[8] A. L. Putri, Maison, Darmaji, "Kerjasama Dan Kekompakan Siswa Dalam Pembelajaran Fisika Di Kelas XII MIPA SMAN 3 Kota Jambi,” Edu Fisika: Jurnal Pendidikan Fisika, vol.3 no.2, pp. 32-40, 2018.

[9] A. Fujika, E. Anggreini, R.S. Budiarti, "Analisis Kemampuan Berfikir Kritis Siswa SMAN 5 Kota Jambi Melalui Pembelajaran Berbasis Masalah Pada Konsep Pencemaran Lingkungan,” Jurnal Biodik, vol. 1 no. 1, pp. 1-10, 2015.

[10] M. Naswir, Haryanto, and Ferawati, “Analisis Keterlaksanaan Model Pembelajaran Inkuiri Tertimbang Untuk Materi Sifat Koligatif Larutan dan Pengaruhna Terhadap Kemampuan Beroikir Kreatif Siswa Kelas XII IPA SMA Islam Al-Falah Kota Jambi,” J. Indo. Soc Integ.Chem, vol. 9, no. 2, pp.43-51, 2016.

[11] E. Sari, Syamsurizal, and Asrial, "Pengembangan Lembaga Kegiatan Peserta Didik (LKPD) Berbasis Karakter Pada Mata Pelajaran Kimia SMA,” Edu-Sains, vol. 5, no. 2, pp. 8-17, 2016.

[12] Dewi, R.S. Budiarti, and M. Aina, "Pengembangan Lembar Kegitaan Peserta Didik (LKPD) Bermuatan Pendidikan Karakter Dengan Model Pembelajaran Guided Inqury Pada Materi Bakteri Bagi Siswa Kelas X Sekolah Menengah Atas," Jurnal Biodik, vol. 3, no.1, pp. 17-26, 2017.

[13] P. M. Purbosari, "Pembelajaran Berbasis Proyek Membuat Ensiklopedia Ilmu Pengetahuan Alam (IPA) Untuk Meningkatkan Academic Skill Pada Mahasiswa,” Scholaria, vol. 6, no. 3, pp. 231-238, 2016.

[14] Nurdyansyah, and L. Riananda, "Developing ICT-Based Learning Model to Improve Learning Outcome IPA of SD Fish Market in Sidoarjo," Proceeding of International Research Clinic and Scientific Publications of Educational Technology, 2016. 
[15] B.B. Akpan, "Innovation In Science And Technology Education Through Science Teacher Associations," International Council of Associations For Science Education, vol. 21, no. 2, pp. 67-69, 2010.

[16] S.Pransiska, R. Asyhar, and Asrial, "Pengaruh Penerapan Model Pembelajaran Group Investigation Dan Motivasi Terhadap Hasil Belajar Siswa Kelas VII Di SMP Dalam Pembelajaran IPA Terpadu Pada Materi Asam, Basa Dan Garam,” Edu-Sains, vol. 5, no. 2, pp. 27-31, 2016.

[17] R. D. Yediarni, Maison, and A. Syarkowi, "Scientific Reasoning Abilities Profil Of Junior High School Students In Jambi," International Journal of Science And Education, vol. 3, no. 1, pp. 21-25, 2019.

[18] R. Galuh, "Hubungan Keterampilan Berpikir Kritis dan Literasi Sains pada Pembelajaran IPA Terpadu dengan Model PBM dan STM,” JPPI, vol. 2, no.2, pp. 131-146, 2016.

[19] Maison, Syahrial, Syamsurizal, and Tanti, "Learning, Environment, Students' Beliefs, And Self-Regulation In Learning Physics: Structural Equation Modelling,” Journal of Baltic Science Education, vol. 18, no. 3, pp. 389-403, 2019.

[20] H. Siregar, "Kreativitas Siswa dalam Mata Pelajaran IPA," Journal Evaluation in Education (JEE), vol. 1, no.1, pp. 21-26, 2020.

[21] U. Sulistyo, A. Mukminin, K. Abdurrahman, and E, Haryanto, "Learning to Teach: A Case Study of Student Teachers' Practium and Policy Recommendations," The Qualitative Report, vol. 22, no. 3, pp. 712-731, 2017.

[22] A. Parnawi, "Psikologi Belajar", Yogyakarta: Deepublish, 2019.

[23] F. A. Nai, "Teori Belajar dan Pembelajaran Implementasinya Dalam Pembelajaran Bahasa Indonesia Di SMP, SMA, dan SMK", Yogyakarta: Deepublish, 2017.

[24] Astalini, Maison, M. Ikhlas, and D. A. Kurniawan, "Pengembangan Instrumen Sikap Mahasiswa Terhadap Mata Kuliah Fisika Matematika," Edusains, vol. 10, no. 1, pp. 46-52, 2018. Pada Materi Fluida Statik untuk Sekolah Menengah Atas," Edu-Sains, vol. 4, no. 2, pp. 30-36, 2015.

[25] H. Mayasari, Syamsurizal, and Maison, "Pengembangan Lembar Kerja Siswa (LKS) Berbasis Karater Melalui Pendekatan Saintifik

[26] Aunurrahman, "Belajar dan Pembelajaran", bandung: Alfabeta, 2013.

[27] W. Astuti, and F. Kristin, "Penerapan Model Pembelajaran Teams Games Tournament Untuk Meningkatkan Keaktifan Dan Hasil Belajar IPA,” Jurnal ilmiah sekolah dasar, vol. 1, no. 3, pp. 155-162, 2017.

[28] A. N. Pour, L. Herayanti, and B. A. Sukroyanti, "Pengaruh Model Pembelajaran Talking Stick Terhadap Keaktifan Belajar Siswa,” Jurnal Penelitian dan Pengkajian Ilmu Pendidikan E-Saintika, vol. 2, no. 1, pp. 36-40, 2018.

[29] M. Effendi, "Integrasi Pembelajaran Active Learning Dan Internet-Based Learning Dalam Meningkatkan Keaktifan Dan Kreativitas Belajar,” Jurnal Pendidikan Islam, vol. 7, no. 2, 2013.

[30] O. D. T. Maharani, and Firosalia, "Peningkatan keaktifa dan hasil belajar IPS melalui model pembelajran kooperatifa tipe make a match,” Wacana akademika: majalah ilmiah kependidikan, vol. 1, no. 1, pp. 4-5, 2017.

[31] N. W. Suitriani, N. W. Arini, and N. N. Gaminah, "Penerapan Model Course Review Horay Berbantuan Media Monopilo Untuk Meningkatkan Keaktifan Dan Hasil Belajar IPA,” e-Journal PGSD Universitas Pendidikan Ganesha, vol. 4, no. 1, pp. 1-10, 2016.

[32] P. D. Hurd, “Active Learning,” Journal of Pharmacy Teaching, pp. 29-47, 2000.

[33] K. Wolfe, “Active Learning," Journal of Teaching In Travel \& Tourism, pp. 7-82, 2006.

[34] T. A. Roman, and Uttachandani, "Researching Pedagogy Within Small Sctive Learning Classrooms: Examing Enacted Pedagogies pf Learner And Instructor Interactions," International Journal Of Research \& Method In Educational, pp. 1-21, 2018.

[35] T. Hardini, "Peningkatan Keaktifan Dan Hasil Belajar Siswa Dalam Pembelajaran PKN Melalui Metode Sosiodrama di Kelas 5 SD Tlompakan 01 - Tuntang,” Jurnal Scholaria, vol. 5 no. 3, pp. 120-135, 2015.

[36] Ramlah, D. Firmansyah, and H. Zubair, "Pengaruh Gaya Belajar dan Keaktifan Siswa Terhadap Prestasi Belajar Matematika (Survey Pada SMP Negeri di Kecamatan Klari Kabupaten Karawang,” Jurnal Ilmiah Solusi, vol 1, no. 3, pp. 68-75, 2014.

[37] J. W. Creswell, "Research Design: Qualitative, Quantitative, and Mixed Methods Approaches", London: SAGE, 2014.

[38] Emosda., and E. P. Anggraini, E. P, “ Hubungan Gaya Mengajar Guru Dengan Kekatifan Belajar Siswa Sekolah Dasar,” Jurnal Gentala, vol. 3, no. 1, pp. 93-110, 2018.

[39] L. M. Cohen, "Research Methods in Education,” New York: Routledge, 2007.

[40] Y. Wicaksana, Wardono, and Ridho, "Analisis Kemampuan Literasi Matematika Dan Karakter Rasa Ingin Tahu Siswa Pada Pembelajaran Berbasis Proyek Berbantuan Schoology,” Unnes Journal of Mathematics Education Research, vol. 6, no. 2, pp. 167-174, 2017.

[41] Widiastuti, and R. H. Santosa, "Pengaruh Metode Inkuiri Terhadap Ketercapaian Kompetensi Dasar, Rasa Ingin Tahu, dan Keammpuan Penalaran Matematis," PYTHAGORAS: Jurnal Pendidikan Matematika, vol. 9, no.2, pp.196-204, 2014.

[42] R. P. Yudha, “27 Karakter Tokoh Indonesia”, Kalimantan Barat: PGRI Prov Kalbar, 2019. 
[43] D. A. Hartati, and P. Hardianto, "The Application of Fusion Learning Model Talking Stick and Course Review Horey To Increase Activeness and Learning Outcomes," Classroom Action Research Journal, vol. 1, no. 3, pp. 117 124, 2017.

[44] P. Virtanen, H. Niemi, and A. Nevgi, "Active learning and self-Regulation Enhance student teachers professional competence," Australian Journal of Teacher Education, vol. 42, no. 12, 2017.

[45] F. Aksit, H. Niemi, and A. Nevgi, "Why Is Active Learning So Difficult To Implement: The Turkish Case," Australian Journal of Teacher Education. Vol. 41, no. 4, pp. 94-109, 2016.

[46] D. S. Putri, and Mawardi, "The Application Of Teams-Games-Tournament (Tgt) To Increase Students' Activeness And Learning Outcomes," Jurnal Pendidikan dan Pengajaran, vol. 50, no. 2, pp. 60-68, 2017.

[47] A. Kara, "The Effect of a 'Learning Theories' Unit on Students' Attitudes Toward Learning.,"Australian Journal of Teacher Education, vol. 34, no.1, 2009.

[48] I. Nuryasintia, and L. A. Wibowo, “). Learning Activeness Through Learning Media and Class Management," Advances in Economics, Business And Management Research. Vol. 65, pp. 145-148, 2019.

[49] W. Winarso, "Assessing The Readiness Of Student Learning Activity And Learning Outcome," Jurnal Pencerahan, vol. 10, no. 2, pp.74-88, 2016.

[50] S. Rahmawati, B. Subali, and Sarwi, "The Effect of Ethnoscience Based Contextual Learning Toward Students' Learning Activity,” Journal of Primary Education, vol. 8, no. 2, pp. 152-160, 2019.

[51] Suardi, and H. Kanji, "Lecture Model of Student Transfer Discussion Method to Increase Student's Activeness and Learning Outcomes,” EST Journal of Educational Science and Technology, vol. 4, no. 1, pp. 48-54, 2018.

[52] N. R. Fitriani, A. Widiyatmoko, and M. Khusniati, "The Effectiveness Of CTL Model Guided Inquiri-Based In The Topic Of Chemicals In Daily Life To Improve Students' Learning Outcomes And Activeness. Jurnal Pendidikan IPA Indonesia, vol. 5, no. 2, pp. 278-283, 2016.

[53] A. Damayanti, E. Tarmedi, and Jupri, "Implementing Cooperative Script Type of Cooperative Learning Model To Improve Students' Activeness in Learning Social Studies,” International Journal Pedagogy Of Social Studies, vol. 3, no. 1, pp. 129-136, 2018. 